\title{
ACCELERATING CULTURAL HERITAGE TOURISM IN SAN ANTONIO: A COMMUNITY-BASED TOURISM DEVELOPMENT PROPOSAL FOR THE MISSIONS HISTORIC DISTRICT
}

\author{
S. DOGANER \& W. DUPONT \\ The University of Texas at San Antonio, College of Architecture, San Antonio, TX, USA.
}

\begin{abstract}
Cultural heritage tourism is a proven economic stimulus that creates jobs and direct economic benefits to locals. Heritage zones promote conservation of historic resources and can incubate small businesses, revitalize commercial districts, generate local jobs and foster positive change in a community. The social benefits are many, yet long-term retention of the benefits requires deliberate planning. The prosperity brought by the tourists tends to destroy the experiences they seek. Heritage tourists seek experiences of authentic cultural heritage. Yet, the economic prosperity of tourism can swiftly alter a region. Business and real estate development pressures increase as the tourist market expands, bringing changes that occlude and displace the local heritage. This paper posits that attention to cultural sustainability can mitigate negative impacts and correlate to a robust heritage tourism economy.

Sustainable development practices can support cultural heritage tourism in a manner that sustains the local culture. The San Antonio Missions and potential development in South San Antonio are reviewed here as an economic development tool designed to attract visitors to an area based on the unique aspects of the locality's history, landscape and culture. The heritage tourism market needs cultural heritage in order to grow and retain the economic prosperity over time.

This research investigates and analyzes the potential of the San Antonio Missions Historic District toward community-based cultural heritage tourism. The connections of Missions to the river will feature historic and artistic interpretations of the story of the missions and highlight their social and cultural importance to the area. This will reinforce the importance of the river to the missions and encourage visitors to circulate between the Mission Reach and the river. Accelerating tourism in Missions Historic District will be a considerable economic and social benefit through the workforce, income and infrastructure developments. This research provides a legacy of positive development within the Missions Historic District, especially as San Antonio moves toward World Heritage designation.

World Heritage designation brings international attention and increased tourism with both positive and negative impacts. Cultural heritage tourism can bring many benefits to a local economy but it can also disrupt the quality of life of the local inhabitants. This research also investigates how to prevent gentrification and the loss of authenticity while tourism in the district accelerates. This paper also promotes cultural and environmental sustainability at the local or neighborhood level, and highlights the potential benefits for small business owners to connect to the growing heritage tourism economy of the San Antonio Missions Historic District. Prosperity for residents of the district is a viable path to sustaining the community's cultural heritage, identity and authenticity. Keywords: Authenticity, community-based design, cultural heritage tourism, management, sustainability, World Heritage designation.
\end{abstract}

\section{INTRODUCTION}

Tourism is one of the world's fastest-growing industries and businesses. International tourist arrivals grew by over 4\% in 2011 to 980 million, according to the latest UNWTO World Tourism Barometer. The Americas $(+4 \%)$ saw an increase of 6 million arrivals, reaching 156 million in total. North America, with a 3\% increase, hit the 100 million tourists mark in 2011 [1]. According to the Economic Impact of San Antonio's Hospitality Industry report, from 1998 to 2008, the economic impact of the hospitality industry increased by more than 70\%. In San Antonio alone, hospitality industry employs more than 113,000 workers who annually generate $\$ 12.2$ billion dollars back into the local economy; making tourism one of the San Antonio's largest industries [2]. 
San Antonio is one of the State's top tourist cities, and a major tourism destination nationally. The city has a rich and unique historic urban landscape characterized by its river with its famous 'Riverwalk', historic neighborhoods and major landmarks such as San Antonio Missions, which are on the U.S. 'tentative list' as possible UNESCO World Heritage Sites (WHS). It is expected that the river improvement project will also reinforce the connection to the San Antonio Missions, and encourage visitors to circulate along the river beyond the downtown area.

The Missions of San Antonio are poised for consideration by the UNESCO World Heritage Committee for inscription as a WHS. The area to be inscribed includes the locally designated Missions Historic District along the San Antonio River in the south section of the city. This zone originally attracted both prehistoric Indian and historic colonists of Spain because of the prevalence of unique natural resources. The historic San Antonio River has long served as the heart of the city. The worldrenowned 'Riverwalk' or 'Paseo del Rio' draws millions of visitors annually, yet miles of urban river with untapped economic potential exist downstream. Local government has completed a multi-year project to restore and enhance the San Antonio River three miles north and 10 miles south of the central plaza. The 'Mission Reach' segment of this project overlays with the research area of this paper, and provides a physical link to the geographic center of the city where tourism is presently concentrated. Mission 'Portals' connect the river to the four historic mission properties in the southern zone - Mission Concepcion, Mission San Jose, Mission San Juan and Mission Espada.

World Heritage designation brings international attention and increased tourism with both positive and negative impacts. Cultural heritage tourism not only can bring many benefits to a local economy but it can also disrupt the quality of life of the local inhabitants. This research also investigates how to prevent gentrification and the loss of authenticity while tourism in the district accelerates. Cultural and environmental sustainability at the local or neighborhood level can produce multiple benefits, including benefits for small business owners to connect to the growing heritage tourism economy of the San Antonio Missions Historic District. Prosperity for residents of the district is a viable path to sustaining the community's cultural heritage, identity and authenticity [4].

The connections of Missions to the river is planned to feature historic and artistic interpretations of the story of the missions and highlight their social and cultural importance to the area. This will reinforce the importance of the river to the missions and encourage visitors to circulate between the Mission Reach and the river. The projected acceleration of tourism in the Missions Historic District

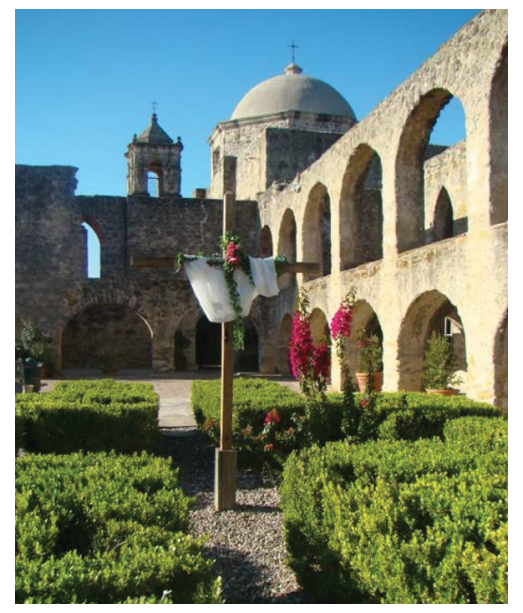

Figure 1: Mission San Jose (photograph taken by Doganer, 2012). 
will be a considerable economic and social benefit through workforce, income and infrastructure developments. Research on World Heritage designations [3] indicates the potential for a legacy of positive development within the Missions Historic District, especially as the San Antonio moves toward World Heritage designation [4].

This research investigates and analyzes the potential of the San Antonio Missions Historic District toward community-based cultural heritage tourism. Literature review, economic impact studies, surveys, one-to-one interviews, community and focus group meetings, and analysis of site, maps, plans and reports are the essential parts of this research. The research will provide information on authentic values of the district, historic significance of buildings, unique features, existing conditions, site infrastructure and cultural heritage tourism potentials, and help researchers define the list of potential entrepreneurs and their properties. The project proposes to assist 12 small business entrepreneurs on their processes to get involved with cultural heritage activities. The project will continue with the architectural drawings of selected entrepreneurs' properties, business consultancy, training seminars, destination marketing studies and the implementation of the project.

\section{MANAGEMENT OF CULTURAL HERITAGE TOURISM}

Heritage is a broad concept and encompasses landscapes, historic places, sites and built environments, as well as biodiversity, collections, past and continuing cultural practices, knowledge and living experiences. It records and expresses the long processes of historic development, forming the essence of diverse national, regional and local identities and is an integral part of modern life. It is a dynamic reference point and positive instrument for growth and change [5,6].

At a time of increasing globalization, most countries encourage the preservation of heritage as an asset for their community. It can be used to evoke a sense of continuity of culture, enrichment of people's lives, as a link with the past and to allow society to make sense of the present. Heritage sites provide a wide range of tourist attractions and generate economic activity for the area. They are also very valuable resources for formal and informal education, and focal points for their communities' identity. Heritage sites provide the tangible links between past, present and future and ideally cultural heritage tourism should bring economic benefits to host communities and provide a significant means and motivation for them to manage their cultural heritage and continuing traditions $[6,7]$.

Tourism is a positive force for the preservation of the heritage sites because of its ability to draw world attention to the area and generate income for heritage conservation. Park [8] states, 'This point is of paramount significance in that tourism serves as a major economic resource for conserving the past.' However, there are increasing and ongoing conflicts among the ideas of heritage conservation and tourism development, and there is a need to find the balance between two. The growing popularity of heritage tourism can be attributed as a destructive force to the long-term sustainability of heritage sites and places if it is not properly managed. Careful consideration in both sustaining a sense of place and maximizing economic potential is critical to the successful management of heritage tourism, since the failure to manage the flux of tourists often leads to putting heritage sites in danger [8].

Management of heritage sites has become a widely discussed concept in the last 10 years after it was highlighted in the 'Operational Guidelines for the Implementation of the World Heritage Convention' [9] and the guide for 'Management Plans for World Heritage Sites' was published by UNESCO German Commission in 2008 [10]. The management plans are thought to be the implementation tools for achieving a balance between the conservation and restoration of cultural heritage, the priorities and needs of local community, and development of tourism and economy. A management plan takes the task of a framework that set forth the guidelines for future decisions, and aims to ensure conservation of significance and values of the site and its sustainability and to help the local community and visitors in appreciating the significance and values of the site. 
A successful management with a major focus on heritage interpretation and presentation ensures that one complements the other. It enables the critical balance to be maintained between the needs of the resources and the needs of the visitors [6]. Management of heritage sites is of pivotal significance in enhancing and enriching tourists' experience and appreciation while fostering a sense of local cultural identity [8]. Orbasli [11] states:

'Visitor management is not only a matter of traffic or pedestrian flow management, but also involves imaginative solutions to enhance the visitor experience, maintain a favorable reputation for the destination, while at the same time ensuring a high-quality environment for residents to live and work in, and visitors to enjoy. Chosen visitor strategies have to respond to specific needs and remain appropriate to the local culture.' [11]

\section{SAN ANTONIO MISSIONS HISTORIC DISTRICT}

The locally designated Missions Historic District spans nearly eight miles from north to south, encompassing four San Antonio Missions sited along the San Antonio River. These eighteenth century complexes include monumental stone buildings built in the Spanish Vernacular tradition, along with associated support buildings, farmlands and acequias [12].

Some mid-nineteenth century residential properties remain in the Missions Historic District as well. Development in the surrounding area mostly dates from the late nineteenth century to the mid-twentieth century, including simple and modestly scaled residential and commercial buildings [12, 13].

\subsection{San Antonio Missions}

Spain colonized and established San Antonio with five mission compounds and a small military base in the eighteenth century. These missions blended native traditions with newly adopted Spanish ways, and created a unique culture. The communities still remain in the area and are a very important part of San Antonio's rich cultural heritage [3, 13].

The City's 'Missions Historic District,' located along the San Antonio River in the south section of the city, includes the lower four missions (Listed from north to south: Concepcion, San Jose, San Juan Capistrano and Espada), their acequias and fields. The area originally attracted both prehistoric Indian and historic Spanish and Anglo populations because of the prevalence of unique natural resources. The abundant water, game and other natural foods seem to have provided prehistoric Indians with an ample non-agricultural subsistence type of lifestyle based upon hunting, gathering and fishing. The area was utilized for agricultural purposes as well as local industries after the establishment of the Spanish Missions [14].

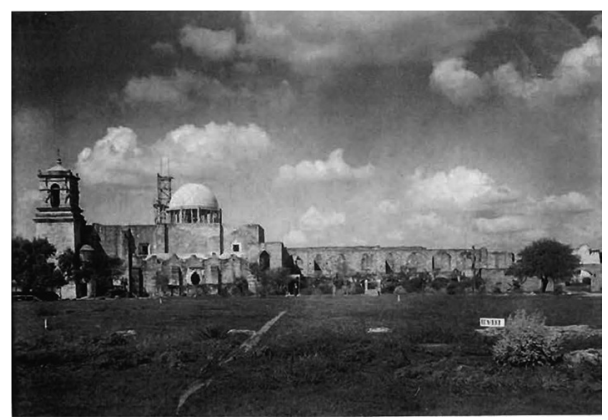

Figure 2: Restoration of Mission San Jose, showing dome under construction in1936 [15, p. 139]. 
The report for the 'Nomination to the World Heritage List' [15] submitted in January 2014 proposes the 'Statement of Outstanding Universal Value' of the Missions as below:

'Situated along a 12.4-kilometer (7.7-mile) stretch of the San Antonio River basin in southern Texas are five Spanish colonial mission complexes built in the early eighteenth century. This ensemble is the most complete and most intact example of the Spanish Crown's efforts to colonize, evangelize, and defend the northern frontier of New Spain during the period when Spain controlled the largest empire in the world. These missions were the center of efforts to evangelize the area's indigenous population into converts loyal to the Catholic Church; they also include all the components required to establish self-sustaining, socio-economic units comprised of Spanish-speaking subjects loyal to the Crown. The missions' more than fifty standing structures, archaeological resources, and landscape features include labores, a rancho, residences, a grist mill, granaries, workshops, wells, lime kilns, churches, conventos, and perimeter walls for protection. The ensemble of missions includes extensive irrigation systems of acequias (one operating continuously for more than 265 years), dams, and an aqueduct that enabled agricultural independence.

These water distribution systems are a clear demonstration of the exceptionally inventive interchange that occurred between indigenous peoples, missionaries, and colonizers that contributed to a fundamental and permanent change in the cultures and values of all involved, but most dramatically in those of the Coahuiltecans and other indigenous hunter-gatherers who, in a matter of one generation, became successful settled agriculturists. The enclosed layout of each mission complex and their proximity to each other, the intensive communal activities such as construction and farming undertaken there, the widespread sharing of knowledge and skills among their inhabitants, and the early adoption of a common language and religion resulted in a people and culture with an identity neither wholly indigenous nor wholly Spanish that has proven exceptionally persistent and pervasive.' [15]

\subsection{Demographics}

San Antonio River South Area Coordinated Management Plan [16] defines the demographic profile of the River South area as below:

'Between 1990 and 2008 the population within this area decreased slightly (1\%) while San Antonio increased by $37 \%$. Residents within the corridor are 5\% of the City's total population (approximately 66,000) and density averages 4.92 persons per acre. The median age is 32.7 years, slightly younger than San Antonio's average of 34 years. Almost $43 \%$ of the population 25 years and older, in this area has not completed a high school education... Educational attainment ties with income potential and discretionary spending. This area earns $\$ 30,630$, nearly $\$ 11,000$ less than the City average... Housing data shows that most residential structures account for $23 \%$ of the land use. They were built during the post WWII era and have a current median value of $\$ 54,843$ compared to the City of San Antonio average of $\$ 113,988$. Other major land uses in the area include parks $21 \%$, institutional $22 \%$, and commercial and vacant land both at 14\%.' [16]

Analysis reveals numerous challenges to the area such as: declining population, lower educational levels, median income and higher poverty levels when compared with the overall City data. Currently of great concern in the River South neighborhoods is the crime rate. This alone has caused many neighborhood areas to rally and work for expanded team efforts with schools, churches, civic organizations and the City for revitalization to strengthen its viability and discourage criminal activity [4]. 


\subsection{Current planning studies and projects}

Current planning studies and investments around the Missions Historic District are San Antonio River Improvements Project/Mission Reach Ecosystem Restoration and Recreation, River South Area Coordinated Management Plan, South Central San Antonio Community Plan, Heritage South Sector Plan, Roosevelt Corridor Reinvestment Plan and Citywide Design Guidelines for Historic Districts [4].

- San Antonio River Improvements Project/Mission Reach Ecosystem Restoration and Recreation: While the Riverwalk draws many millions of visitors annually, the eight miles of urban river within the Missions Historic Districtlies are economically stagnant. The comprehensive, multi-year, 'Mission Reach' improvements have enhanced the river and made the district physically accessible as well available as a recreational and tourism resource with untapped potential. Current efforts to develop the full potential of the San Antonio River are focusing on two sections of the river - the 'Museum Reach' to the north of main plaza and the Mission Reach located in South San Antonio. Each area poses different challenges. The enhancements are expected to have far-reaching benefits for all of San Antonio, from increased economic development to cultural resources and recreational opportunities connecting neighborhoods. The Mission Reach segment provides a strong connection between the area and downtown. The Mission Reach Ecosystem Restoration and Recreation Project is transforming an 8-mile stretch of the San Antonio River into a quality riparian woodland ecosystem. As the Mission Reach project restores the natural ecosystem of the river, it will also reconnect the river to the historic Missions that relied on it hundreds of years ago. Mission Portals will connect San Antonio's four historic missions - Mission Concepcion, Mission San Jose, Mission San Juan and Mission Espada - to the San Antonio River. These connections will feature historic and artistic interpretations of the story of the missions and highlight their social and cultural importance to the area. This will reinforce the importance of the river to the missions and encourage visitors to circulate between the Mission Reach and the river. River Improvements Project planners are also working closely with the National Park Service San Antonio Missions National Historic Park to ensure that there is a seamless transition between the Mission Reach and the historic missions, and the proposed project helps to strengthen this transition [16].

\section{- River South Area Coordinated Management Plan:}

Bexar County, the City of San Antonio, the National Park Service, and the San Antonio River Authority developed this coordinated management plan in 2010 to protect the community's heritage and investment. The Management Plan incorporates recommendations and actions that promote the coordination of land use, infrastructure, and the economic, recreational, and cultural development in the Mission Reach area and adjacent neighborhoods [15]. The investment of time, funding and improvements at both the street and River levels is a key to this area realizing its full potential as an attractive, viable corridor. The management plan encourages economic diversity and job creation, which are compatible with San Antonio's natural and cultural resources; preserves and revitalizes existing housing through community heritage-based economic development and promotes targeted infill for new housing neighborhood improvements [16].

\section{- South Central San Antonio Community Plan:}

The South Central San Antonio Community Plan, adopted in 1999 and updated in 2003, covers the northern portion of River South to SW Military Drive. Plan elements cover neighborhood and com-

munity development, community facilities, transportation and quality of life. Emphasis is on infill development, housing stock and improving the quality of commercial corridors. A chief goal is to 
'enhance and improve the Missions, parks and the San Antonio River' through strategies aimed at zoning, safety, accessibility and restoration [16].

\section{- Heritage South Sector Plan:}

By 2035, Bexar County is projected to have a population of approximately 2.1 million residents. Heritage South Sector Plan focuses on sustainable growth options for the southern portion of the City of San Antonio and Bexar County. The Sector Plan addresses key issues related to transportation, utilities and infrastructure, housing, land use, community facilities and services, education, parks and natural resources, historic preservation, economic development and tourism. It promotes a community fabric that is vibrant, attractive and valued [15].

\section{- Roosevelt Corridor Reinvestment Plan:}

The Roosevelt Corridor Reinvestment Plan, adopted in 2009, includes four registered neighborhood associations in River South - Roosevelt Park, Riverside South, Mission San Jose and East Pyron/ Symphony Lane. The goal for the Corridor is to encourage reinvestment in the Roosevelt corridor; Launch community-based initiatives to improve quality of life, Link existing business and property owners with funding sources, Create investment opportunities [16].

\section{- Citywide Design Guidelines for Historic Districts:}

The Citywide Design guidelines provide to historic district residents, property owners, professionals working with historic properties and potential construction applicants an understanding of architectural design principles and guidelines [4, 12].

Besides these ongoing projects, National Park Services has also proposed and developed studies that would support the cultural heritage tourism activities and sustain the communities and the culture that the missions helped spawn. Some of these initiatives are 'A Day in the Life of the Missions' hands-on cultural demonstration programming at Mission San José, a Spanish colonial demonstration farm on mission labores land at Mission San Juan, which will entail both new construction and new programming, and building a new park headquarters and research center, and restoring the landscape around Mission San José [2].

\subsection{World Heritage Site Designation}

The WHS nomination of the San Antonio Missions will be reviewed by ICOMOS in 2014 and considered by the Committee in 2015. It would be the first WHS in the State of Texas and only the 22nd WHS inscribed in the United States [17]. Recognition as a WHS would put the missions in the company of fewer than 1,000 places around the world that are recognized for outstanding cultural or natural values [18].

WHS status could bring enhanced resources for conservation and additional funding and investment, and benefit nearby communities from increased visitation and tourist spending. These communities could also contribute to local economic development and revitalization [3]. The new report on potential economic impact of WHS designation funded by Bexar County indicates that WHS designation could be both an outstanding promotional opportunity and a high-profile catalyst for developing more significant cultural and heritage tourism in the area. The Harbinger Consulting Group [3] states, 'Cultural travelers, whether domestic or international, look for experiences that are unique to a place. The World Heritage Site can be used to capture the attention of these potential visitors, but they will be looking for other high quality, engaging, authentic cultural experiences to augment their WHS visit. Use WHS designation as a catalyst for developing and connecting other heritage tourism opportunities and local businesses.' 


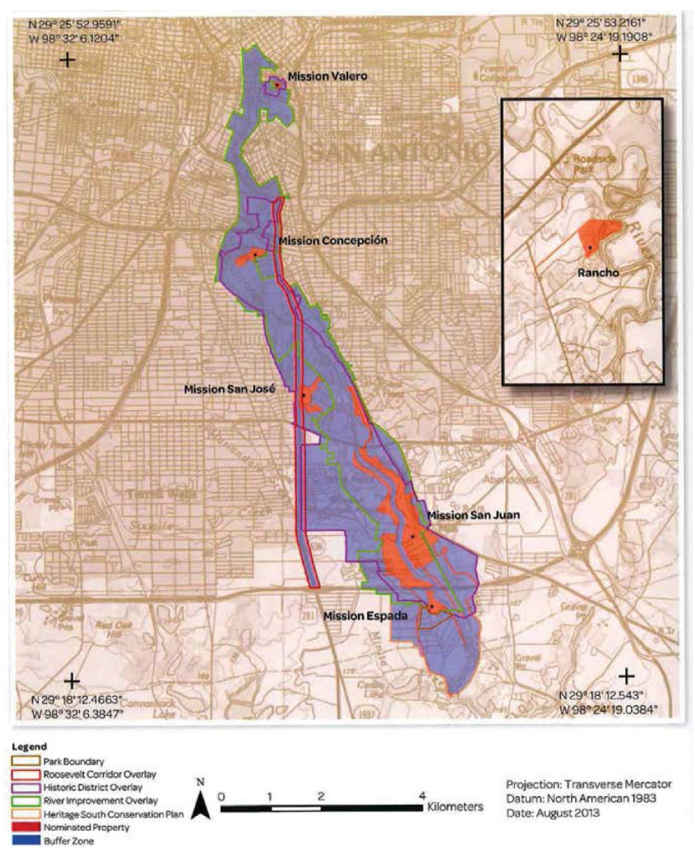

Figure 3: WHS buffer zone overlays [15, p. 260].

Three significant improvements around the San Antonio Missions are coming together, which will give the World Heritage application a major boost; they include:

- $\$ 15.5$ million in improvements and an endowment for the Mission churches sponsored by the Las Misiones, a non-profit entity.

- $\$ 358$ million San Antonio River improvement project managed by the San Antonio River Authority and funded by Bexar County, City of San Antonio and U.S. Corps of Engineers.

- \$4 million San Juan Demonstration Farm funded by Bexar County and Los Compadres de San Antonio Missions [17] - expected to be operational in 2013, the farm could attract more than 240,000 visitors to a demonstration Spanish colonial farming interpretive program [2].

As the river trails and mission portals are completed, and projects such as the demonstration farm at Mission San Juan come online in the next few years, visitor activity is projected to steadily increase [2]. Ten years after presumed designation of the Missions WHS (2025), annual economic benefits for Bexar County are expected to range from $11 \%$ to $26 \%$ above the impacts the Alamo and San Antonio Missions National Historical Park would generate regardless of World Heritage status. Economic benefits grow with collaboration, promotion and use of the WHS to catalyze additional cultural heritage tourism [3,13].

\subsubsection{The management plan for the San Antonio Missions}

Buildings and infrastructure to support increased visitation are already in place. The National Park Service (NPS) was the principal author of a management plan for the core heritage zones to be inscribed. The NPS plan addresses the balance between the desires and interests of visitors and the protection and conservation of the resources that sustain the property's Outstanding Universal Value. The focus is on the primary heritage resources and tangible values like buildings and view sheds. 
The intangible culture, embodied in uses, traditions, language and people, is more difficult to protect with a management plan.

The overall management plan for the San Antonio Missions was developed by the advisory committee for the World Heritage nomination, completed and signed in December 2013. The plan formalizes the partnerships on transportation corridors, signage, educational programs and site management. The advisory committee for the World Heritage nomination meets on a regular basis to discuss development issues, conservation plans, visitor use, traffic flow between portions of the nominated property and other issues as needed. The committee also works together to promote the nominated property through community events, a website, an e-newsletter and social media [15].

The NPS, the Archdiocese of San Antonio, and all landowners within the National Park boundary have a cooperative agreement on management of different areas within the mission compounds and maintenance standards. Basically, any structure that is currently used for religious purposes cannot be managed by the NPS due to the Consitutional mandate for separation of church and state. The mission churches are State Antiquity Landmarks and thus all preservation projects within the nominated property are reviewed by the Texas Historical Commission [15].

\section{OUTSTANDING UNIVERSAL VALUE}

Inscription as a UNESCO WHS requires Outstanding Universal Value (OUV). According to the World Heritage Operating Guidelines, the term OUV means "cultural and/or natural significance which is so exceptional as to transcend national boundaries and to be of common importance for present and future generations' [9].The OUV of a cultural site is all about historical significance, but conditions of authenticity and integrity must be met, as well. A range of authenticity and integrity attributes are defined in the Operational Guidelines, and these appear in Table 1 to show which ones are present in San Antonio and to what degree. All of these attributes have potential market value for cultural heritage tourism [13].

Integrity is the ability of a property to convey its historic significance [19]. Authenticity is the degree to which a historic site and its surrounding context convey information about the past honestly and accurately [13]. In this case, the integrity and authenticity of the OUV is diminished if the current residents are displaced, because the intangible culture of the residents is part of the OUV. The probable form of displacement will be real estate sales, followed by demolition and new development, all incentivized by the increased tourism traffic. The intangible heritage of the Missions Historic District includes language, music, food, traditions and events. These intangibles are part of the authenticity and integrity of the historic zone [13].

The San Antonio Missions are considered eligible for inscription as a WHS because of the cultural landscape that displays a high level of intactness as well as an essential continuity of use from past to present. The place retains the authenticity of continuous use by the descendants of the people who created it. The residents and their contemporary culture are the essential ingredients of the experiential value sought by the tourists.

The threat of population displacement includes real estate development for large-scale hotels and chain/franchise restaurants. Additionally, people may choose to live elsewhere if immediately adjacent to commercial 'strips' dominated by automobile traffic and parking lots. Some businesses may pander to the tourists by offering packaged experiences of a 'bygone era' which lack accuracy. In actuality, the authentic cultural experiences sought by the visitors - the heritage resources that they spend money to access - include the intangible local culture along with the buildings and grounds of the Spanish Colonial Missions. The people of the place hold the keys to their own economic vitality.

Sustainability is often defined as meeting the needs of the present without compromising the needs of the future. Ultimately, the matter concerns the needs of people and includes the cultural identify of people. Defined more precisely, then, sustainability is perpetual maintenance of the 
Table 1: Attributes of authenticity and integrity of the colonial missions in San Antonio [13].

\begin{tabular}{|c|c|c|c|c|c|}
\hline $\begin{array}{l}\text { Attributes of World Heritage } \\
\text { Outstanding Universal Value } \\
\text { (OUV). All OUV values are relevant } \\
\text { to the intact cultural landscape of } \\
\text { the Colonial Missions in San } \\
\text { Antonio }\end{array}$ & $\begin{array}{l}\text { Tangibly } \\
\text { embodied } \\
\text { in built } \\
\text { features }\end{array}$ & $\begin{array}{l}\text { Embodied } \\
\text { in the } \\
\text { local } \\
\text { population }\end{array}$ & $\begin{array}{l}\text { Degree } \\
\text { present in } \\
\text { San } \\
\text { Antonio }\end{array}$ & $\begin{array}{l}\text { Concern: } \\
\text { tourist } \\
\text { numbers } \\
\text { may } \\
\text { damage }\end{array}$ & $\begin{array}{l}\text { Threat by } \\
\text { insensitive } \\
\text { economic } \\
\text { growth }\end{array}$ \\
\hline \multicolumn{6}{|l|}{ AUTHENTICITY Attributes } \\
\hline $\begin{array}{l}\% \text { of intactness of the physical form } \\
\text { and design }\end{array}$ & Yes & No & High & Concern & No \\
\hline $\begin{array}{l}\text { Material surviving from historic } \\
\text { period }\end{array}$ & Yes & No & High & Concern & No \\
\hline $\begin{array}{l}\text { Use/function survives from the } \\
\text { historic period }\end{array}$ & No & Yes & Low & No & No \\
\hline $\begin{array}{l}\text { Traditions, techniques and } \\
\text { management system surviving from } \\
\text { the period of operation }\end{array}$ & No & Yes & Med & No & No \\
\hline $\begin{array}{l}\text { Location/setting of the buildings } \\
\text { survive from historic period (not } \\
\text { reconstructed or moved) }\end{array}$ & Yes & No & High & Concern & Threat \\
\hline \multicolumn{6}{|c|}{$\begin{array}{l}\text { Language and other forms of intangible heritage associated with the place continue to present day } \\
\text { (historic culture remains the dominant culture in the immediate context) RE: a, b, and c below }\end{array}$} \\
\hline $\begin{array}{l}\text { a. Retains a high degree of its } \\
\text { historical, cultural context, i.e. the } \\
\text { original culture is still dominant } \\
\text { culture in the immediate context of } \\
\text { the Mission }\end{array}$ & No & Yes & High & No & Threat \\
\hline $\begin{array}{l}\text { b. Buildings and grounds are } \\
\text { in regular use associated with } \\
\text { historical functions }\end{array}$ & No & Yes & Med & Concern & No \\
\hline $\begin{array}{l}\text { c. Events connected to period of } \\
\text { operation continue today }\end{array}$ & No & Yes & Med & Concern & No \\
\hline $\begin{array}{l}\text { Spirit and feeling (see paragraph } 85 \\
\text { of the Operational Guidelines) }\end{array}$ & Yes & No & Med & Concern & Threat \\
\hline $\begin{array}{l}\text { Low degree of reconstruction } \\
\text { (paragraph } 86 \text {, page 22) which } \\
\text { means higher authenticity }\end{array}$ & Yes & No & High & No & No \\
\hline
\end{tabular}

INTEGRITY: a measure of the wholeness and intactness of the cultural heritage and its attributes Extent to which the property Yes No High Concern Threat includes elements necessary to express its OUV 


\begin{tabular}{|c|c|c|c|c|c|}
\hline $\begin{array}{l}\text { Attributes of World Heritage } \\
\text { Outstanding Universal Value } \\
\text { (OUV). All OUV values are relevant } \\
\text { to the intact cultural landscape of } \\
\text { the Colonial Missions in San } \\
\text { Antonio }\end{array}$ & $\begin{array}{l}\text { Tangibly } \\
\text { embodied } \\
\text { in built } \\
\text { features }\end{array}$ & $\begin{array}{l}\text { Embodied } \\
\text { in the } \\
\text { local } \\
\text { population }\end{array}$ & $\begin{array}{l}\text { Degree } \\
\text { present in } \\
\text { San } \\
\text { Antonio }\end{array}$ & $\begin{array}{l}\text { Concern: } \\
\text { tourist } \\
\text { numbers } \\
\text { may } \\
\text { damage }\end{array}$ & $\begin{array}{l}\text { Threat by } \\
\text { insensitive } \\
\text { economic } \\
\text { growth }\end{array}$ \\
\hline $\begin{array}{l}\text { Extent to which the property size } \\
\text { ensures full representation of } \\
\text { the features and processes which } \\
\text { convey the property's significance }\end{array}$ & Yes & No & High & No & Threat \\
\hline $\begin{array}{l}\text { Current, physical condition of } \\
\text { materials and systems are good }\end{array}$ & Yes & No & High & Concern & No \\
\hline $\begin{array}{l}\text { Impact of deterioration processes } \\
\text { controlled; permanent maintenance } \\
\text { process that avoids or greatly } \\
\text { minimizes reconstruction of } \\
\text { elements }\end{array}$ & Yes & No & High & Concern & No \\
\hline $\begin{array}{l}\% \text { of elements necessary to convey } \\
\text { the totality of the value conveyed } \\
\text { by the property is high; no question } \\
\text { of what might have existed because } \\
\text { nothing is missing }\end{array}$ & Yes & No & Med & No & No \\
\hline $\begin{array}{l}\text { Relationships and dynamic } \\
\text { functions in cultural landscapes, } \\
\text { historic towns or living properties } \\
\text { essential to distinctive character are } \\
\text { maintained }\end{array}$ & Yes & Yes & High & Concern & Threat \\
\hline
\end{tabular}

natural and cultural systems that support human existence. Included are concerns for the environment, access to economic prosperity, social welfare and heritage issues. Cultural sustainability concerns the conservation and perpetuation of cultures, the common identities of heritage that connect people to places.

\section{A COMMUNITY-BASED CULTURAL HERITAGE TOURISM PROJECT FOR THE SAN ANTONIO MISSIONS HISTORIC DISTRICT}

Cultural heritage tourism is a proven economic stimulus that creates jobs and direct economic benefits to locals. Tourism industry supports the protection of cultural heritage for future generations of the host community and visitors, and co-operation between the stakeholders is a basic necessity for a sustainable tourism industry [7]. The involvement and co-operation of local community representatives, conservationists, tourism operators, property owners, policy makers, those preparing national development plans and site managers is necessary to achieve a sustainable cultural heritage tourism industry and enhance the protection of heritage resources for future generations [5]. The management plans are intended to form a framework for different topics for achieving a balance to be maintained between the needs of the stakeholders and the necessities for the sustainability of the heritage site. 
The development of community-based cultural heritage tourism is critical to achieve sustainable development; thus communities can improve their living conditions without disappearing and/or losing their authenticity, and without irreversibly damaging the environment [20]. Expected outcomes from a community-based program include:

- Creating jobs through the development of a tourism infrastructure.

- Developing new, and enhancing current, tourism products.

- Providing training and capacity building.

- Ensuring that the projects are sustainable in the long term [21].

In this context, the UTSA Center for Cultural Sustainability has proposed a community-based cultural heritage tourism project in the Missions Historic District as a unique development model. A group of faculty with an expertise on architecture and planning, conservation, business and tourism, have worked together and developed a community-based cultural heritage tourism model. This model is just a project proposal now to be developed further when funded [13]. The proposed project has presented to the City and County officials, community associations and several City committees, and got their support. This community-based cultural heritage tourism fits perfectly into the management plan for the San Antonio Missions and current planning studies and projects explained in Sections 3.3 and 3.4.

The concept PROPOSED for this project is to engage Mission Historic District residents in small business development. The purpose of this project is to create prosperity for residents of San Antonio's Mission Historic District. It means to promote the continuity of heritage through the benefits, which come from cultural heritage tourism. The project aims to provide technical preservation guidance and cultural heritage tourism knowledge to potential small business owners in reuse of existing, historic buildings and properties for new businesses. Prospective entrepreneurs will receive training and professional support to tap into the tourist economy that flows right past their front doors, and in turn, their efforts will support and sustain the cultural heritage of their community.

The proposal addresses the issues of cultural and environmental sustainability at the local or neighborhood level while giving tourists an option to experience the cultural heritage of the region. Studying the potential of the San Antonio Mission Historic District and encouraging sustainable cultural heritage tourism and related small-scale economic activities in the area will promote sustainable local economic development [4].

This project focuses on the potential of new business uses for existing buildings and properties in the Mission Historic District, while planning sustainable, opportunity rich and economically competitive communities. The proposed project promotes cultural and environmental sustainability at the local or neighborhood level while giving tourists an option to experience the cultural heritage of the region.

The proposed project aims to provide individual property owners with a package of offerings. Highlights include:

Training workshops on Cultural Heritage Tourism including coverage of the financial aspects of Heritage Tourism.

- Training workshops on historic preservation and re-use of existing buildings.

- Business plans for small business owners, including marketing plans, social media and information on area micro-lenders.

- Community planning meetings and workshops.

- Architectural design as well as workshops and services geared to revitalization efforts [4, 13]. 
The objectives of the full life of the proposed project are: to effectively communicate the values of heritage tourism; the conservation of cultural resources and the inclusion of community in decision making.

To create a plan with the greatest opportunity for success, the project group would engage with the local community to ensure that professional and scholarly collaboration is led by the community's vision for their own prosperity. The project includes three components that utilize public participation in every level of the project. Architecture and planning, tourism and business groups will work together to develop a successful community-based cultural heritage tourism project in the Missions Historic District.

The proposed geographic area of this plan is scaleable and flexible to accommodate needs and expectations. The project group will integrate with the ongoing efforts of other city agencies and with the community's interests to designate the locations best suited for implementation of the project. Targeting zones such as portals to the river and other key areas will be a vital component of the project [4].

This community-based cultural heritage tourism project is a 3-year project.

\subsection{Year 1}

The objectives for year 1 are:

- to identify the target area(s),

- to determine the capacity, value and potential re-use of structures and properties within the proposed area,

- to identify resident entrepreneurs for participation in the project, and

- to provide entrepreneurs with business tools for success.

The deliverables for year 1 will include project report, project information web page, education and training opportunities, and list of potential resident entrepreneurs.

A. Project report

The project group will compile a comprehensive report that includes the sections detailed below. Each section will also be submitted for review as work is being completed. The project report will include a brief narrative of the historic context of the district and findings from previous analyses. The report will include photographs and maps, site design analysis, cultural heritage tourism market analysis, identification of the project target area and architectural inventory [4].

- Site design analysis:

This will be the first step in identifying the potential for heritage tourism businesses in the Missions Historic District as well as determining the area(s) best suited for the project. It will consist of two elements: review of previous planning studies and field survey and research around the Missions.

Review of previous planning studies: The proposal aims to build on the comprehensive regional plans for the Missions Historic District in order to augment the community vision. An analysis of existing documents will aid in identifying the locations best suited to the project. The documents for this analysis include but are not limited to: the 'Roosevelt Corridor Reinvestment Plan,' the San Antonio River Improvements Project's 'Mission Reach Ecosystem Restoration and Recreation Project,' the 'River South Area Coordinated Management Plan' and the 'South Central San Antonio Community Plan.' Guidelines issued by the City of San Antonio Office of Historic Preservation and recommendations from the San Antonio City Design Center will be included in the analysis. 
Field survey and research around the Missions (concentrated radius around the Missions and Mission Portals within the Missions Historic District): The architecture and planning group will conduct a field survey of the area surrounding the Missions in order to gather visual data on existing structures and properties. Observations from the field survey and analysis of GIS maps will provide information on qualities such as authenticity, historic significance, unique features, existing conditions, site infrastructure and cultural heritage tourism potentials. The survey will include photographs and generated GIS maps [4].

\section{- Cultural heritage tourism market analysis:}

Concurrent with the site design analysis, the tourism group will conduct a market analysis to determine the nature of current cultural heritage activity and potential future activity. The analysis will have two components: a survey of visitors to the Missions and focus group(s).

A survey of visitors to the Missions: A visitor survey will be conducted of visitors to the missions (excluding the Alamo) to determine a visitor profile and obtain visitor perceptions of the tourism facilities and services. Visitor surveys will be performed at the four missions and other high volume areas within the heritage district. Information gathered from the visitor survey will be used to provide recommendations for promoting tourism for the Missions Historic District.

Focus group(s): A focus group of 10-12 people including managers of the historic mission sites, local community leaders and managers of other tourism operations in the district will be held to gain a better understanding of their strategies, perceptions of heritage tourism and the current status of research efforts regarding tourists. If necessary, a second group will be held to accommodate all interested parties [4].

\section{- Identification of the Project's Target Area(s):}

The project group will identify the target area(s) for the proposed project in collaboration with city and county officials and community residents. Identification of the area will be determined using information gathered from the field survey and meetings with community residents.

\section{- Architectural inventory:}

Upon determination of the target area, the architecture and planning group will prepare an architectural inventory of selected (up to 25) properties in the target area. The inventory will include: address, estimated date of construction, property type, historic significance, unique features, size, structural and nonstructural systems and materials, existing conditions, site infrastructure, and architectural and historical integrity of the surveyed properties. This inventory will be used to assess and evaluate the potential re-use of the properties [4].

B. Project information Web page:

Project progress as well as the final report will be made available on a project website, for better community awareness. Limited quantities of printed editions of the report will also be made available for those without Internet access [4].

C. Education and training:

There will be two types of education and training opportunities: community meetings on cultural heritage tourism and business plan training.

- Community meetings on cultural heritage tourism:

The focus groups (see Market Analysis) will be followed by one or more 'town hall' meetings, with local community leaders, managers of tourism operations in the district and district residents. Findings from the Site Design and Market Analyses will be presented in these meetings. The objectives 
of the meetings are to raise awareness of the benefits of Cultural Heritage Tourism, obtain information regarding community perceptions of the tourism industry in the district, determine if there are any areas of concern, seek potential entrepreneurs, identify the project's target areas and ensure the community is involved in decision-making in developing and implementing the project.

\section{- Business plan training:}

Potential and existing entrepreneurs will be given the opportunity to attend business plan training seminars. The aim of these seminars is to provide small business owners with the knowledge needed to start and grow a business. The training will include how to write a business plan and find financing. The training will be open to public participation, but limited to 100 participants [4].

D. List of potential entrepreneurs:

The project group will identify and recommend 10-12 candidates and their properties for the next phases of the project (Years 2 and 3). The candidates will be identified based on results from the business planning seminars, the site analysis and the building inventory [4].

\subsection{Year 2}

$*$

The objective for year 2 is to take the project from planning to implementation. The project group will assist the selected participants by providing architectural design plans, and planned business and marketing strategies, in order to foster and nurture sustainable small business practices [4].

The deliverables for year 2 will include architectural drawings, business consultancy and community training seminars.

A. Architectural drawings:

Ten to 12 architectural projects including plans, sections and elevations will be provided to the selected potential entrepreneurs. Drawings will be suitable for submission to the Historic and Design Review Commission (HDRC).

\section{B. Business consultancy:}

Advanced training and consultancy will be given to the 10-12 selected potential entrepreneurs.C. C. Community training seminars:

Training seminars will be provided to selected business owners and service employees of tourism and hospitality organizations. Potential and existing entrepreneurs will also be given the opportunity to attend the essentials of starting a business seminar (open to public, but limited to 100 participants) [4].

\subsection{Year 3}

The objective for the third and final year of the proposed project is to implement all aspects of the project, including administration and monitoring of construction, business plans and outreach to tourists [4].

The deliverables for the final year of the project will include consultancy on implementation of the projects, destination marketing studies and final report.

By the end of the third year, selected entrepreneurs will be trained on how to run a small business on cultural heritage tourism, financially assisted and supported, and ready to start up their own businesses. They will also be done with the construction and/or renovation of their own properties [4].

Summary of deliverables of the proposed 3-year project are shown in Table 2:

The proposed 3-year community-based cultural heritage tourism project is expected to develop 12 new, small businesses. Projections are based on UTSA South-West Texas Border and San Antonio 
Table 2: Summary of deliverables of the proposed project [4].

\begin{tabular}{|c|c|c|}
\hline YEAR 1 & YEAR 2 & YEAR 3 \\
\hline $\begin{array}{l}\text { A. Project report } \\
\text { - Site design analysis } \\
\text { - Cultural heritage tourism } \\
\text { market analysis } \\
\text { - Identification of the proj- } \\
\text { ect target area } \\
\text { - Architectural inventory } \\
\text { B. Project information Web } \\
\text { page } \\
\text { C. Education and training } \\
\text { - Community meetings on } \\
\text { cultural heritage tourism } \\
\text { - Business plan training } \\
\text { D. List of potential resident } \\
\text { entrepreneurs }\end{array}$ & $\begin{array}{l}\text { A. Architectural drawings } \\
\text { B. Business consultancy } \\
\text { C. Community training } \\
\text { seminars }\end{array}$ & $\begin{array}{l}\text { A. Consultancy on } \\
\text { implementation of the } \\
\text { projects } \\
\text { B. Destination marketing studies } \\
\text { C. Final report }\end{array}$ \\
\hline
\end{tabular}

Small Business Development Centers 2012 Annual Reports [22, 23] and The Harbinger Consulting Group's report on 'Building on a Strong Foundation: Potential Economic Impact of World Heritage Site Designation for the San Antonio Missions' [3].

Projected economic impacts of the proposed project are:

- 12 new businesses have the potential to create $41-63$ jobs.

- With 12 new businesses there is potential for $\$ 3.2-\$ 3.5$ million in new financing and investments.

- The 12 new businesses are expected to generate $\$ 307,000-\$ 370,000$ in new tax revenue.

\section{CONCLUSIONS}

Sustainability is the perpetual maintenance of the natural and cultural systems that support human existence. Included are concerns for the environment, access to economic prosperity, social welfare and heritage issues. Cultural sustainability is the conservation and perpetuation of cultures, the common identities of heritage that connect people to places and is key to a robust heritage tourism economy that can empower residents and enhance quality of life within a heritage zone.

For more than a century, the San Antonio Missions have been one of the most important tourist destinations in Texas. Now, they are focal points for new economic development along the river. While 1.7 million people visit the Missions each year, the impact of those visits has not translated to positive economic development for the local community. The proposed community-based cultural heritage project would highlight the tourism potentials of the district, capitalize the public investments and improvements around the San Antonio Missions, and encourage the revitalization of the Missions Historic District. The area will regain its sense of identity and share its treasures of history, culture and heritage with all who visit and seek for authenticity.

World Heritage designation of the San Antonio Missions will bring international attention to the district. The Harbinger Consulting Group [3] states, 'Cultural travelers, whether domestic or international, look for experiences that are unique to a place. The World Heritage Site can be used to 
capture the attention of these potential visitors, but they will be looking for other high quality, engaging, authentic cultural experiences to augment their WHS visit. Use WHS designation as a catalyst for developing and connecting other heritage tourism opportunities and local businesses.' World Heritage inscription can bring increased tourism with both positive and negative impacts. WHS designation could be both a promotional opportunity and a high-profile catalyst for developing more important cultural heritage tourism in the Missions Historic District [3]. The benefits brought by tourism to a local economy are obvious, yet the potential negative impacts are more difficult to manage. Tourism can disturb or diminish the quality of life of the local residents [24]. Throughout the development process, the whole Missions Historic District, not only the Historical Park managed by the U.S. National Park Service, needs to be well managed or it may lose its authenticity and so its attractiveness to visitors. Thus, the proposed community-based cultural heritage tourism project will fit perfectly into the management plan for the San Antonio Missions and is very important and timely in order to support and connect community small business owners to the existing heritage tourism economy while planning the inevitable tourism development, as well [4].

Cultural heritage tourism has ample capacity to create prosperity for a community, strengthen the area's viability, and improve quality of life for residents. The proposed community-based cultural heritage tourism project aims to develop successful, locally managed businesses in the District that will engender initiatives by other local business entrepreneurs resulting in a 'ripple' effect $[4,13]$. Finally, it is expected that the proposed project would be a unique sustainable development opportunity that will mitigate gentrification, prevent loss of authenticity, encourage people to rehabilitate their existing properties and create prosperity for the residents of Mission Historic District while sustaining the community's cultural heritage and identity of their community.

\section{ACKNOWLEDGEMENTS}

We thank Susan Snow (Archaeologist, National Park Service), Claudia Guerra (Program Coordinator, UTSA Center for Cultural Sustainability) and David Bojanic, D.B.A (Anheuser-Busch Foundation Professor of Tourism, UTSA College of Business) for their support and collaboration on this project proposal.

\section{REFERENCES}

[1] Kester, J.G.C., 2011 International Tourism Results and Prospects for 2012, UNWTO News Conference, HQ, Madrid, Spain, 16 January 2012, available at http://dtxtq4w60xqpw.cloudfront.net/sites/all/files/pdf/unwto_hq_fitur12_jk_2pp_0.pdf (accessed 03/03/2012).

[2] UTSA Institute for Economic Development's Center for Community and Business Research in conjunction with The Harbinger Consulting Group, Economic Impact of the San Antonio Missions, National Historic Parks: USA, 2011, available at http://ccs.utsa.edu/pdf/EconomicImpactMissions.pdf (accessed 03/03/2012).

[3] The Harbinger Consulting Group, Building on a Strong Foundation: Potential Economic Impact of World Heritage Site Designation for the San Antonio Missions, Bexar County, Texas, USA, 2013, available at: http://www.bexar.org/whs/Missions_WHS_Report.PDF (accessed 03/03/2012).

[4] Doganer, S., Cultural heritage tourism research: a sustainable community-based design project for the San Antonio Mission Historic District, WIT Transactions on Ecology and the Environment, 173, pp. 219-230, 2013, ISSN 1743-3541, doi. 10.2495/SDP130181. doi: http://dx.doi. org/10.2495/sdp130181 
[5] International Cultural Tourism Charter, Managing Tourism at Places of Heritage Significance, ICOMOS International Council on Monuments and Sites, Mexico, 1999, available at http:// www.icomos.org/charters/tourism_e.pdf (accessed 03/27/2013).

[6] Doganer, S., Lombardi, A. \& Tumer, E.U., Managing heritage sites while accelerating cultural heritage tourism in Antalya, Turkey, Heritage, Architecture and Land Design Focus on Conservation, Regeneration, Innovation, XI Internazionale di Studi, 13-15 June, Capri/Italy, pp. 227-235, 2013.

[7] Cros, H., A new model to assist in planning for sustainable cultural heritage tourism, International Journal of Tourism Research, 3(2), pp. 165-170, 2001. doi: http://dx.doi.org/10.1002/ itr.297

[8] Park, H.Y., Heritage Tourism, Routledge: London, 2014. doi: http://dx.doi.org/10.4324/ 9781315780436

[9] UNESCO World Heritage Center, Operational Guidelines for the Implementation of the World Heritage Convention, Intergovernmental Committee for the Protection of the World Cultural and Natural Heritage: Paris, France, 2013, available at http://whc.unesco.org/archive/ opguide13-en.pdf (accessed 12/24/2013).

[10] Ringbeck, B., Management Plans for World Heritage Sites - A Practical Guide, German Commission for UNESCO: Bonn, 2008, available at http://www.unesco.de/fileadmin/medien/Dokumente/Bibliothek/Management_Plan_for_Wold_Heritage_Sites.pdf (accessed 03/18/2013).

[11] Orbasli, A., Tourists in Historic Towns: Urban Conservation and Heritage Management, Spon Press: London, 2000. doi: http://dx.doi.org/10.4324/9780203479001

[12] City of San Antonio, Office of Historic Preservation, A Guide to San Antonio's Historic Resources, Texas, USA, 2012, available at http://www.sanantonio.gov/historic/HistoricDistrictGuidelines.aspx (accessed 12/24/2013), http://www.sanantonio.gov/historic/Docs/DesignGuidelines/7_GuidetoSanAntonio'sHistoricDistricts.pdf (accessed 12/24/2013).

[13] Doganer, S. \& Dupont, W., Cultural heritage tourism and authenticity: San Antonio Missions Historic District, WIT Transactions on The Built Environment, 131, , pp. 15-27, 2013. ISSN 1743-3509, doi. 10.2495/STR130021.

[14] City of San Antonio, Office of Historic Preservation, Local Historic Districts, Mission, Texas, USA, available at http://www.sanantonio.gov/historic/Districts/Mission.aspx (accessed 03/03/2012).

[15] Ringenbach, P.T., Snow, S., Morris, S., et al., San Antonio Missions, Nomination to the World Heritage List by the United States of America, San Antonio, Texas, USA, 2014.

[16] Snow, S., San Antonio Community Leaders Launch, Quest for World Heritage Status", August 22, U.S. Department of the Interior, National Park Service, USA, 2012, available at http:// www.nps.gov/saan/parknews/world-heritage-quest.htm (accessed 03/27/2012).

[17] UNESCO World Heritage Center, Tentative List: San Antonio Franciscan Missions, available at http://whc.unesco.org/en/tentativelists/5247/ (accessed 03/03/2012).

[18] Bexar County, City of San Antonio, San Antonio River Authority, and others, San Antonio River South Area Coordinated Management Plan, Protect-Promote-Coordinate, Texas, USA, 2010, available at http://www.sanantonioriver.org/images/RiverSouth_Management_ plan_12_08_2010.pdf (accessed 03/03/2012).

[19] National Register Bulletin 15, How to Apply the National register Criteria for Evaluation, U.S. Department of the Interior, National Park Service, USA, available at http://www.nps.gov/nr/ publications/bulletins/pdfs/NRB15.pdf (accessed 03/27/2012). 
[20] Ruiz-Ballesteros, E., Social-ecological resilience and community-based tourism: an approach from Agua Blanca, Ecuador. Tourism Management, 32(3), pp. 655-666, 2011. doi: http:// dx.doi.org/10.1016/j.tourman.2010.05.021

[21] Leballo, M., The study of best practice in Community-Based Tourism Initiatives (CBTI) in South Africa, Unpublished Paper, Land and Agricultural Policy Center, Johannesburg, 2000.

[22] UTSA South-West Texas Border Small Business Development Center Network, Building the Texas Economy One Business at a Time, 2012 Annual Report, USA, available at http://txsbdc. org/images/documents/2012ar_swtxb.pdf (accessed 12/24/2013).

[23] UTSA San Antonio Small Business Development Center Network, Building the Texas Economy One Business at a Time, 2012 Annual Report, USA, available at http://sasbdc.org/images/ stories/annual_reports/sasbdc-2012-annual-report.pdf (accessed 12/24/2013).

[24] Brooks, G., Exploiting the benefits of World Heritage Listing: Evora, Portugal and Hoi An, Vietnam, City Spaces - Tourist Places: Urban Tourism Precincts, Elsevier: UK, 2008. doi: http://dx.doi.org/10.1016/b978-0-7506-8195-7.00017-2 